\title{
A new experimental model of cigarette smoke-induced emphysema in Wistar rats*,**
}

\author{
Um novo modelo experimental de enfisema induzido \\ por fumaça de cigarro em ratos Wistar
}

\section{Rodrigo de las Heras Kozma, Edson Marcelino Alves, Valter Abraão Barbosa-de-Oliveira, Fernanda Degobbi Tenorio Quirino dos Santos Lopes, Renan Cenize Guardia, Henrique Vivi Buzo, Carolina Arruda de Faria, Camila Yamashita, Manzelio Cavazzana Júnior, Fernando Frei, Maria José de Oliveira Ribeiro-Paes, João Tadeu Ribeiro-Paes}

\begin{abstract}
Objective: To describe a new murine model of cigarette smoke-induced emphysema. Methods: Twenty-four male Wistar rats were divided into two groups: the cigarette smoke group, comprising 12 rats exposed to smoke from 12 commercial filter cigarettes three times a day (a total of 36 cigarettes per day) every day for 30 weeks; and the control group, comprising 12 rats exposed to room air three times a day every day for 30 weeks. Lung function was assessed by mechanical ventilation, and emphysema was morphometrically assessed by measurement of the mean linear intercept (Lm). Results: The mean weight gain was significantly (approximately ten times) lower in the cigarette smoke group than in the control group. The $\mathrm{Lm}$ was $25.0 \%$ higher in the cigarette smoke group. There was a trend toward worsening of lung function parameters in the cigarette smoke group. Conclusions: The new murine model of cigarette smoke-induced emphysema and the methodology employed in the present study are effective and reproducible, representing a promising and economically viable option for use in studies investigating the pathophysiology of and therapeutic approaches to COPD.
\end{abstract}

Keywords: Tobacco smoke pollution; Emphysema; Disease models, animal; Equipment and supplies.

\section{Resumo}

Objetivo: Descrever um novo modelo murino de enfisema induzido pela fumaça de cigarro. Métodos: Vinte e quatro ratos Wistar foram divididos em dois grupos: o grupo fumaça de cigarro, com 12 ratos expostos à fumaça de 12 cigarros comerciais com filtro três vezes ao dia (um total de 36 cigarros por dia), sete dias por semana, durante 30 semanas e o grupo controle, com 12 animais expostos ao ar ambiente três vezes ao dia, sete dias por semana, durante 30 semanas. A função pulmonar foi avaliada por meio de ventilação mecânica, e o enfisema foi morfometricamente avaliado por meio do diâmetro alveolar médio ( $\mathrm{Lm})$. Resultados: A média de ganho de peso foi significativamente menor (aproximadamente dez vezes menor) no grupo fumaça de cigarro do que no grupo controle. $0 \mathrm{~lm}$ foi 25.0\% maior no grupo fumaça de cigarro. Os parâmetros de função pulmonar tenderam a ser piores no grupo fumaça de cigarro. Conclusões: 0 novo modelo murino de enfisema induzido pela fumaça de cigarro e a metodologia empregada neste estudo são eficazes e reproduzíveis; são, portanto, uma opção promissora e economicamente viável para estudos sobre a fisiopatologia e o tratamento da DPOC.

Descritores: Poluição por fumaça de tabaco; Enfisema; Modelos animais de doenças; Equipamentos e provisões.

\footnotetext{
*Study carried out at the Júlio de Mesquita Filho São Paulo State University at Assis School of Sciences and Languages, Assis, Brazil. Correspondence to: João Tadeu Ribeiro Paes, MD, PhD, Laboratório de Genética e Terapia Celular - GentTe Cel, Laboratory of Genetics and Cell Therapy - Departamento de Ciências Biológicas, UNESP, Av. Dom Antonio, 2100, CEP 19806-900, Assis, SP, Brazil. Tel. 5518 3302-5856. E-mail: labcel.tronco@gmail.com

Financial support: This study received financial support from the Fundação para o Desenvolvimento da Unesp (Fundunesp, Foundation for the Development of the São Paulo State University), the Assis City Hall, and the Consórcio Intermunicipal do Vale do Paranapanema/Saúde (CIVAP/Saúde, Paranapanema Valley Intermunicipal Consortium/Health). Rodrigo de las Heras Kozma e Valter A. Barbosa are recipients of grants from the Coordenação de Aperfeiçoamento de Pessoal de Nível Superior (CAPES, Office for the Advancement of Higher Education). Edson Marcelino Alves and Carolina Arruda de Faria are recipients of grants from the Conselho Nacional de Desenvolvimento Científico e Tecnológico (CNPq, National Council for Scientific and Technological Development). Renan Cenize Guardia and Henrique Vivi Buzo are recipients of grants from the Faculdades Integradas Padre Albino (FIPA, Padre Albino Integrated Colleges).
}

Submitted: 30 July 2013. Accepted, after review: 9 December 2013.

${ }^{* *}$ A versão completa em português deste artigo está disponível em www.jornaldepneumologia.com.br 


\section{Introduction}

Worldwide, COPD is an important public health problem, having a high prevalence and carrying high socioeconomic costs. It is currently the fourth leading cause of death worldwide, and estimates indicate that it will be the third by $2020 .^{(1,2)}$

Within the COPD spectrum, emphysema is defined as airspace enlargement distal to terminal bronchioles, accompanied by alveolar wall destruction, without significant fibrosis. Oxidative lung injury and inflammation in response to irritants (such as air pollution and cigarette smoke) speed up functional and morphological changes, gradually limiting gas exchange..$^{(2-4)}$

Given that treatment is limited to palliative care, animal models are central to studies investigating the pathophysiology of COPD and new therapeutic approaches to the disease. Emphysema can be experimentally induced by the use of proteases, by exposure to cigarette smoke, and by genetic manipulation. ${ }^{(3-9)}$

Although animal models of enzymeinduced emphysema constitute an interesting methodological approach, they do not accurately reproduce the mechanisms of alveolar destruction resulting from smoke inhalation in human patients. Proteolytic activity leads to a significant increase in airspace size, not reproducing the sequence of pathological events characteristic of emphysema in humans. ${ }^{(6,10)}$ Animal models of cigarette smoke-induced emphysema are used in an attempt to reproduce human disease, especially the pathophysiological mechanisms involved in the natural history of emphysema. ${ }^{(6,11)}$ However, the duration of smoke exposure and the number of cigarettes used vary widely across models. In general, the most effective results are obtained with chronic exposure periods (> 6 months). ${ }^{(6,12)}$

The objective of the present study was to describe a new experimental model of cigarette smoke-induced emphysema. The model involves Wistar rats and an apparatus developed in the Laboratory of Genetics and Cell Therapy of the Júlio de Mesquita Filho São Paulo State University at Assis School of Sciences and Languages, located in the city of Assis, Brazil. The model can contribute to a better understanding of the pathophysiological processes in COPD, as well as to the development of new treatment strategies.

\section{Methods}

A total of 24 male Wistar rats (age, 12 weeks; weight, 400-450 g) were divided into two groups: the cigarette smoke group, comprising 12 rats exposed to smoke from 12 commercial filter cigarettes (Derby Vibrante; Souza Cruz SA, Rio de Janeiro, Brazil)-containing $0.8 \mathrm{mg}$ of nicotine, $10 \mathrm{mg}$ of tar, and $10 \mathrm{mg}$ of carbon monoxide (CO)-for three 1-h exposure periods (from 8:00 a.m. to 9:00 a.m., from 12:00 p.m. to 1:00 p.m., and from 6:00 p.m. to 7:00 p.m.) every day for 30 weeks; and the control group, comprising 12 rats exposed to room air for three 1-h exposure periods every day for 30 weeks. During each exposure period, the rats in the cigarette smoke group were exposed to smoke from 4 cigarettes for $15 \mathrm{~min}$, followed by a 5 -min rest period (during which room air was delivered to prevent hypoxia). During each 15-min period of exposure, the smoking apparatus was set to cycle with cigarette-suction periods of $10 \mathrm{~s}$ and rest periods of $15 \mathrm{~s}$.

The apparatus consists of an animal containment system and a cigarette smoking device (Figure 1). The animal containment system comprises four metal cages $(24 \mathrm{~cm} \times 17 \mathrm{~cm}$ $\times 15 \mathrm{~cm}$ ) closed at the top. The four cages are placed equidistant from each other inside a hermetically sealed acrylic box $(70 \mathrm{~cm} \times 70$ $\mathrm{cm} \times 20 \mathrm{~cm}$ ). Four large rats or 16 mice can be placed in each cage. Two apparatuses were used in the present study: one for the animals in the cigarette smoke group and one for the animals in the control group. Each apparatus was placed in a separate room. The cigarette smoke delivery system consists of an external cigarette holder connected to a dynamic suction pump by a flexible hose. The pump can be programmed to alternate between periods of cigarette suction and periods of clean air suction, to prevent asphyxia. The pump generates negative pressure, which forces the air through a lit-up cigarette, generating cigarette smoke and pushing it toward the hose and into the acrylic box. The concentration of $\mathrm{CO}$ in the containment system was assessed by means of a CO meter (ToxiPro ${ }^{\oplus}$ Single Gas Detector; Honeywell Analytics Distribution Inc., Lincolnshire, IL, USA) and was found to be $350-400 \mathrm{ppm}$ during the exposure periods.

All animals were weighed weekly on an analytical scale. For standardization purposes, 
(A)

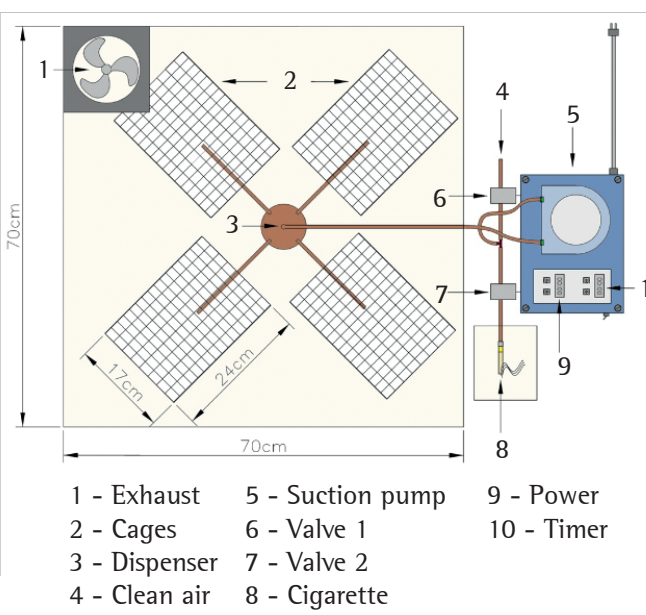

(B)

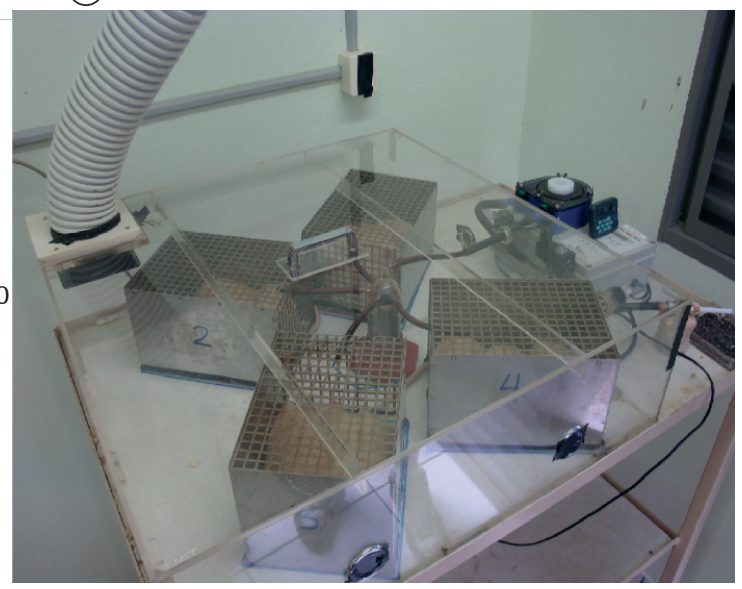

Figure 1 - $\ln$ A, schematic illustration of the smoking apparatus. In B, upper view of the smoking apparatus.

all animals were weighed on the same day of the week and at the same time of day.

lung function was assessed by means of a ventilator for small animals (flexiVent ${ }^{\mathrm{m}}$; SCIREQ, Montreal, QC, Canada). After 30 weeks of daily exposure to mainstream cigarette smoke or room air, the animals were anesthetized by intraperitoneal injection of $250 \mathrm{mg} / \mathrm{kg}$ of Thiopentax ${ }^{\oplus}$ (Cristália - Produtos Químicos Farmacêuticos Ltda., Itapira, Brazil) and tracheostomized with a 20-G catheter connected to the ventilator, which was set to a tidal volume of $10 \mathrm{~mL} / \mathrm{kg}$, an RR of 120 breaths/min, and a positive end-expiratory pressure of $3 \mathrm{CmH}_{2} \mathrm{O}$. Muscle paralysis was induced by intraperitoneal injection of pancuronium bromide ( $1 \mathrm{mg} / \mathrm{kg}$ ). Lung function was expressed as airway resistance (Raw), respiratory system resistance, respiratory system compliance (Crs), tissue damping, and tissue elastance.

After mechanical evaluation of the respiratory system, the animals were euthanized and the lungs were removed. The trachea was cannulated and attached to the perfusion apparatus, the lungs being incubated in 4\% paraformaldehyde solution for $24 \mathrm{~h}$ and kept inflated with sustained positive pressure $\left(20 \mathrm{cmH}_{2} \mathrm{O}\right)$. The lung tissue was cut into 5- $\mu \mathrm{m}$ sections and stained with $\mathrm{H} \& \mathrm{E}$ for histological evaluation.

Emphysema was assessed by measurement of the mean linear intercept $(\mathrm{Lm})$, in $\mu \mathrm{m}$, as proposed by Weibel. ${ }^{(13)}$ After fixation, each lung was cut into four sagittal sections. The sections were embedded in a single paraffin block, and each block was cut into three $5-\mu \mathrm{m}$ sections, three slides being therefore prepared for each block. For each slide, ten randomly selected nonoverlapping fields were examined under light microscopy (magnification, $\times 400$ ).

The results were analyzed by means of the Student's t-test and one-way ANOVA. In order to test the assumptions of normal distribution and homogeneity of variance, we performed the Shapiro-Wilk test and Levene's test. When the assumptions were not met, we used the Mann-Whitney test and Kruskal-Wallis ANOVA. For all tests, values of $p<0.05$ were considered significant. The study project was approved by the Animal Research Ethics Committee of the Julio de Mesquita Filho São Paulo State University at Assis School of Sciences and Languages (Protocol no. 001/2011).

\section{Results}

As can be seen in Figure 2, there were no significant differences between the rats in the cigarette smoke group and those in the control group in terms of their initial weight. From the second week of exposure onward, the mean weight gain was lower in the cigarette smoke group than in the control group. There was a significant difference $(p<0.05)$ between the two groups regarding weight gain after the third week of exposure. After 30 weeks of exposure, the mean weight gain was $212.00 \pm 83.40 \mathrm{~g}$ in the control group and $44.92 \pm 43.40 \mathrm{~g}$ in the cigarette smoke group, the mean weight gain 
in the cigarette smoke group corresponding to $21.2 \%$ of that in the control group.

As can be seen in Table 1, the values of Raw, tissue damping, respiratory system resistance, $\mathrm{Crs}$, and tissue elastance were higher in the cigarette smoke group than in the control group. However, there was no significant difference between the two groups in terms of the respiratory parameters analyzed, which is probably due to the high variation among subjects in the same group (as evidenced by the high SD values).

Figure $3 \mathrm{~A}$ shows the $\mathrm{Lm}$ for the right and left lungs in combination (for each group), and Figure $3 \mathrm{~B}$ shows the $\mathrm{Lm}$ for the right and left lungs in isolation (for each group). As can be seen in Figure 3, there was a statistically significant difference in the $\mathrm{Lm}$ between the cigarette smoke group and the control group. When we analyzed the right and left lungs in combination, we found that the $\mathrm{Lm}$ was $25.0 \%$ higher in the cigarette smoke group than in the control group (Figure $3 \mathrm{~A}$ ). When the right and left lungs were analyzed separately, the $\mathrm{Lm}$ for the left lung was found to be $15.8 \%$ higher in the

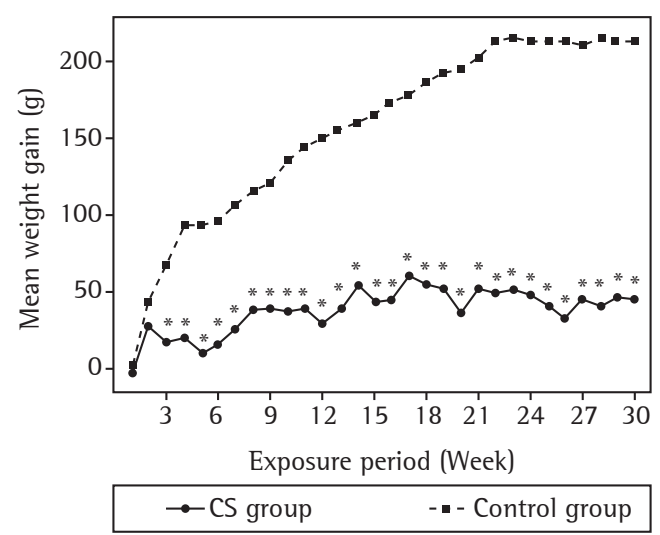

Figure 2 - Mean weight gain in the Wistar rats in the cigarette smoke (CS) group and in those in the control group. ${ }^{*} p<0.05$. cigarette smoke group than in the control group (Figure 3B). Similarly, the $\mathrm{Lm}$ for the right lung was found to be $32.3 \%$ higher in the cigarette smoke group than in the control group (Figure 3B). These results suggest a difference in the degree of airspace enlargement between the right and left lungs in the cigarette smoke group. Alveolar septal destruction was significantly greater in the cigarette smoke group than in the control group, showing airspace enlargement resulting from increased lung parenchymal destruction in the cigarette smoke group, as assessed qualitatively by H\&E staining of histological sections (Figure 4).

\section{Discussion}

Cigarette smoke-induced emphysema has been studied under various experimental conditions. ${ }^{(5,6,11,12,14,15)}$ Although some questions remain regarding the duration of exposure and the number of cigarettes used, animal models of cigarette smoke-induced emphysema are the experimental models that best mimic the clinical features of pulmonary emphysema in human patients and constitute an important tool in the study of the pathophysiological aspects of the disease. ${ }^{(6)}$

Although animal models of cigarette smokeinduced emphysema have been used in several studies, only a few smoke exposure systems are commercially available, including the Cigarette Smoke Generator (TSE Systems, Inc., Chesterfield, MO, USA), the TE-2 Smoking Machine ${ }^{\circledast}$ (Teague Enterprises, Woodland, CA, USA), and the inExpose $^{\mathrm{TM}}$ (SCIREQ). All have similar characteristics, consisting of a cigarette smoke generator and an animal exposure chamber, where animals are confined and exposed to cigarette smoke (via whole-body or nose-only exposure). ${ }^{(11,12,15,16)}$ They all cost approximately US\$75,000.00), which is approximately twenty times the final cost of our apparatus (i.e., US\$3,000.00).

Table 1 - Airway resistance, respiratory system resistance, tissue damping, tissue elastance, and respiratory system compliance in Wistar rats exposed to cigarette smoke (the cigarette smoke group) and in those exposed to room air (the control group).

\begin{tabular}{lccccc}
\hline Groups & Raw $^{\mathrm{a}}$ & Rrs $^{\mathrm{a}}$ & $\mathrm{G}^{\mathrm{b}}$ & $\mathrm{H}^{\mathrm{b}}$ & Crs $^{\mathrm{b}}$ \\
\hline $\mathrm{CS}$ & $0.09 \pm 0.07$ & $0.15 \pm 0.07$ & $0.35 \pm 0.10$ & $1.21 \pm 0.24$ & $1.37 \pm 0.24$ \\
Control & $0.04 \pm 0.02$ & $0.12 \pm 0.07$ & $0.22 \pm 0.18$ & $0.96 \pm 0.89$ & $1.14 \pm 0.25$ \\
\hline
\end{tabular}

Raw: airway resistance; Rrs: respiratory system resistance; G: tissue damping; $\mathrm{H}$ : tissue elastance; Crs: respiratory system

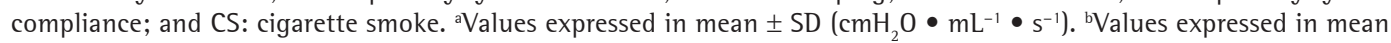
$\pm \mathrm{SD}\left(\mathrm{cmH}_{2} \mathrm{O} \bullet \mathrm{mL}^{-1} \bullet \mathrm{s}^{-(1-\mathrm{a})}\right)$. 

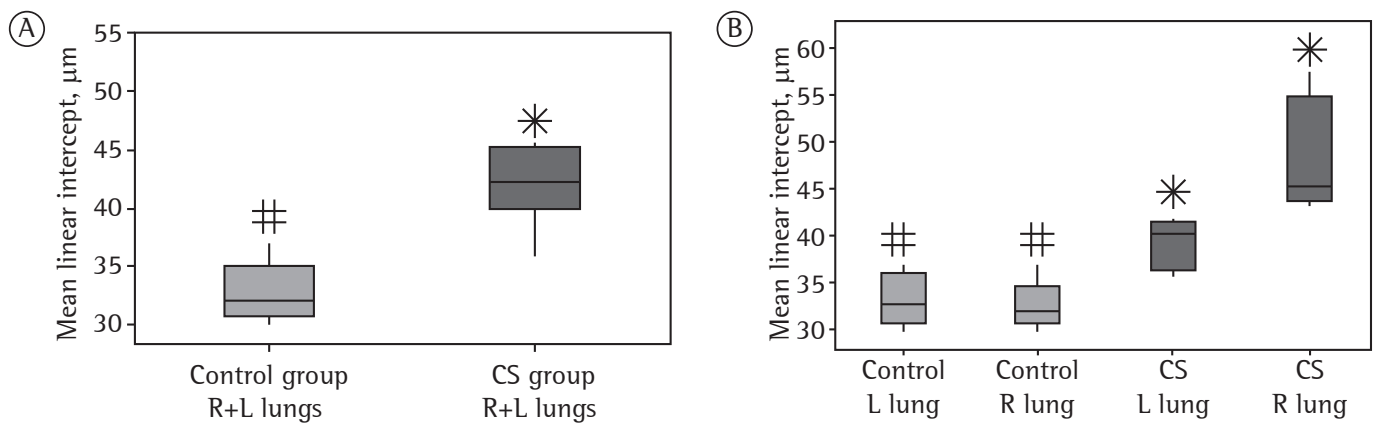

Figure 3 - $\ln$ A, mean linear intercept values (in $\mu \mathrm{m}$ ) for the right (R) and left (L) lungs in combination in the control and cigarette smoke (CS) groups. In B, mean linear intercept values (in $\mu \mathrm{m}$ ) for the R and $\mathrm{L}$ lungs in isolation in the control and CS groups. Different symbols indicate a statistically significant difference ( $p$ $<0.05)$ between medians.

Several features of our apparatus are similar to those of commercially available systems used in previous studies. ${ }^{(11,12,15,16)}$ One interesting feature is that animals are exposed to cigarette smoke via whole-body exposure. Another feature is that the smoke that is pumped into the exposure chamber is generated by the puffing of a cigarette, as occurs during actual smoking. Like other systems on the market, our apparatus allows us to regulate the suction power and the time of cigarette suction, alternating with periods of air suction, by means of a timer. The main advantages of our apparatus over commercially available devices include its low cost, simple design, and ease of installation, as well as the fact that it can be assembled from commercially available parts, such as a suction pump and a timer (to regulate the cigarette-suction and air-suction times, as described in the Methods section). In addition, the cost of our apparatus is 20 times lower than is that of commercially available devices.

The 30-week period of exposure employed in our study was based on a search for a model that offers greater reproducibility with respect to time. Previous studies of cigarette smoke-induced emphysema (employing different apparatuses) have reported exposure periods of 8-36 weeks. Although exposure periods of 6 months are common in animal model studies, ${ }^{(12,15-18)}$ exposure periods of up to 9 months have also been used..$^{(12,19)}$

In some protocols, animals are exposed to cigarette smoke 3-5 days a week, which is not enough to simulate daily smoking..$^{(10,15,18-20)}$ The duration of daily exposure varies widely across studies. ${ }^{(12,21,22)} \mathrm{Li}$ et al. adopted a two-step exposure protocol whereby animals were initially exposed to smoke from 8 cigarettes twice a day for 2 weeks (weeks 1 and 2) and subsequently exposed to smoke from 15 cigarettes three times a day for another 10 weeks (weeks 3-12).(23) The animal model used in the present study simulates the pathophysiological conditions of active smoking, animals having been exposed to mainstream cigarette smoke daily (7 days a week) for 30 weeks.

There are no studies involving a comparative morphometric analysis of alveolar damage in the right and left lungs. Comparative morphometric analysis is relevant because it allows the demonstration of the heterogeneity of parenchymal destruction in experimentally induced emphysema. Anatomical differences between the right and left lungs of rats provide a possible explanation for the results obtained. According to Cataneo and Reibscheid, ${ }^{(24)}$ the rat trachea shows a deviation to the right, and the rat bronchi are similar to the human bronchi (i.e., short and large). The right bronchus appears to be a continuation of the trachea, whereas the left bronchus looks like a branch. ${ }^{(24)}$ Therefore, it is possible that the right lung was more consistently exposed to cigarette smoke, which resulted in intense neutrophil and macrophage activation and increased secretion of proteases responsible for lung parenchymal destruction. These anatomical differences can explain why the $\mathrm{Lm}$ was higher in the right lung than in the left lung in the group of rats exposed to cigarette smoke.

Although functional testing is a valuable tool for assessing the development of emphysema in experimental models, it is less sensitive than morphometric analysis, which is more accurate in the assessment of parenchymal damage. Animals with moderate emphysema usually have normal functional values when compared with healthy 

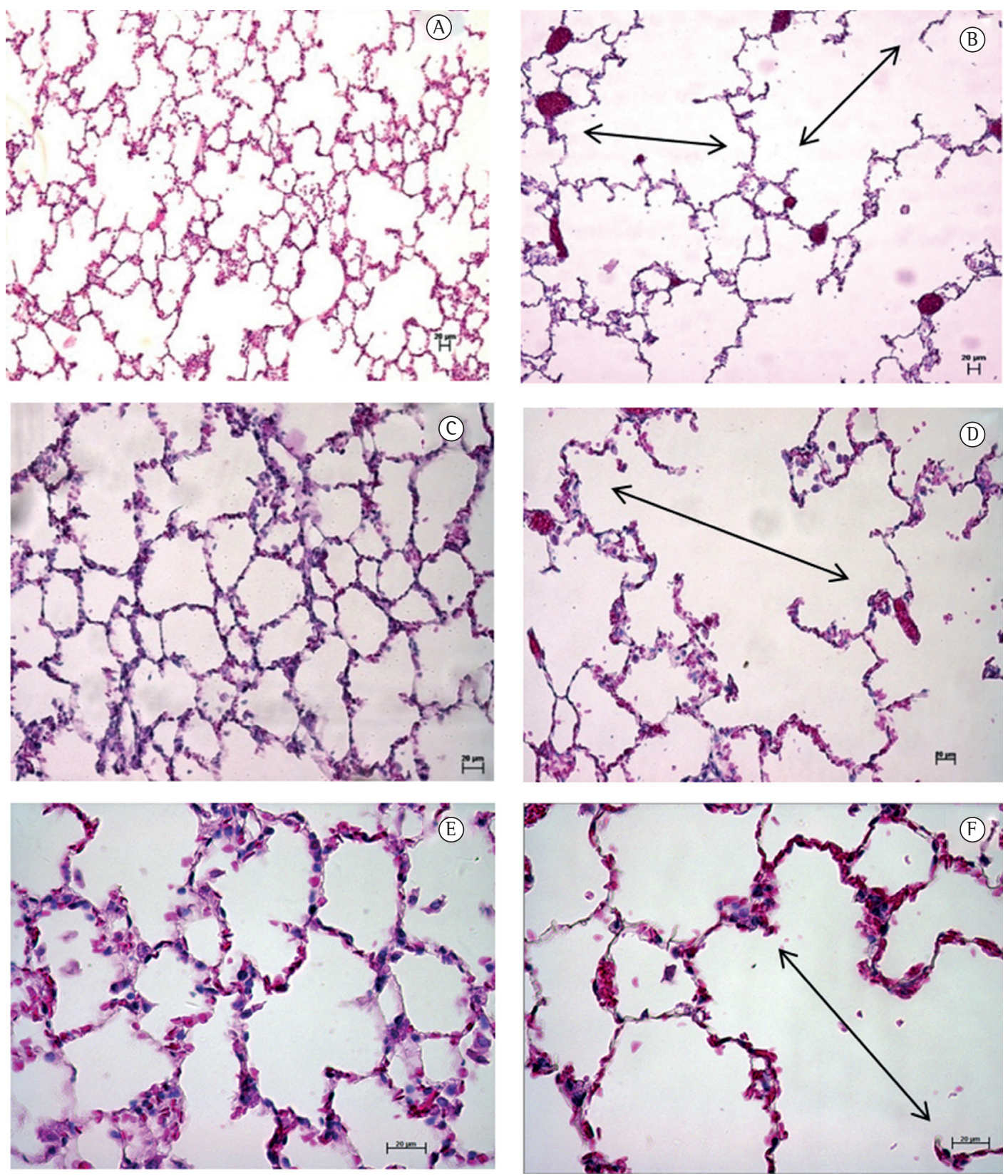

Figure 4 - Photomicrographs of rat lung tissue stained with H\&E (magnification: $\times 100[\mathrm{~A}$ and $\mathrm{B}] ; \times 200[\mathrm{C}$ and D]; and $\times 400$ [E and F]). In A, C, and E, lung tissue from rats exposed to room air (control group). In $\mathrm{B}, \mathrm{D}$, and $\mathrm{F}$, lung tissue from rats exposed to mainstream cigarette smoke. Double arrows indicate merged alveoli resulting in airspace enlargement. Scale bars: $20 \mu \mathrm{m}$.

animals, whereas animals with severe disease show significant changes in respiratory parameters. ${ }^{(6)}$ This has been reported by other research groups. Foronjy et al. ${ }^{(25)}$ exposed two strains of $\mathrm{C} 57$ mice to cigarette smoke for 6 months or 12 months and observed a significant increase in the $\mathrm{Lm}$ in comparison with the respective control groups. Nevertheless, there were no significant differences between the exposed animals and the respective control groups regarding the respiratory parameters. According to Wright et al., ${ }^{(6)}$ animals with moderate emphysema usually show borderline or normal functional values when compared with healthy animals; animals with advanced disease are the only ones that show significant changes in the respiratory parameters. 
The results of the present study showed no significant differences in Raw or Crs between the animals in the cigarette smoke group and those in the control group. However, there was a trend toward increased Raw in the cigarette smoke group. The species under study plays a relevant role in the results of mechanical ventilation. Although Wistar rats allow researchers to perform a series of functional analyses, they are more resistant to the development of emphysema than are other rodent species. ${ }^{(6)}$ From a pathophysiological standpoint, the disease can be milder in rats; this can complicate the comparison of functional parameters between animals that were exposed and unexposed to cigarette smoke. ${ }^{(6)}$ This empirical finding can explain the results of the present study, which showed no statistically significant differences between the two groups of rats regarding the functional parameters assessed (Table 1), despite the morphometric evidence of emphysema (i.e., the $\mathrm{Lm}$ ), as shown in Figure 3.

COPD can be considered a systemic disease, being characterized by skeletal changes, weakness, muscle dysfunction, and weight loss, which is due to oxidative stress and reduced caloric intake. ${ }^{(21,26,27)}$ In smokers with COPD, nicotine increases satiety and reduces food intake, ${ }^{(28)}$ smoking therefore contributing to weight loss, worsening emphysema, and generating a feedback circuit. Previous studies have shown that cigarette smoke can change hypothalamic appetite regulation in the central nervous system..$^{(12,28,29)}$ Mineur et al. ${ }^{(28)}$ demonstrated that nicotine decreases food intake and body weight.

The inflammatory process is a fundamental component of the pathophysiology of COPD. Inflammation and other systemic effects of emphysema were not assessed in the present study, given that our main objective was to evaluate the feasibility of a new murine model of cigarette smoke-induced pulmonary emphysema. Other studies are currently under way in our laboratory, involving analysis of the lung for the presence of metalloproteinases 9 and 12, which play an important role in the inflammatory process, ${ }^{(3)}$ and assessment of inflammatory cells in BAL fluid from animals exposed and unexposed to cigarette smoke.

The sharp weight loss observed in the present study was not due to the exposure period, given the statistically significant difference between the cigarette smoke group and the control group as of the third week of exposure (Figure 2). The animals in the control group showed a mean weight gain of $212.0 \pm 83.40 \mathrm{~g}$, whereas those in the cigarette smoke group showed a mean weight gain of $44.92 \pm 43.40 \mathrm{~g}$, which corresponded to $21.2 \%$ of that in the control group. Our results also showed a large standard deviation regarding the mean weight gain of the exposed animals after 30 weeks (44.92 \pm 43.40 g). These results might be due to the intensity of exposure to cigarette smoke in the present study, which resulted in pulmonary changes and widespread pathophysiological changes. As noted above, COPD should be considered a systemic disease, as in a feedback circuit in which the side effects of smoke exposure determine morphological and functional changes in the lung. These changes reflect and are aggravated by the systemic effects of nicotine and the large number of toxic substances in cigarette smoke and other air pollutants.

The results of the present study indicate that mainstream cigarette smoke leads to decreased weight gain and development of emphysema in exposed animals, as assessed by morphometric analysis (i.e., the $\mathrm{Lm}$ ). The methodology employed in the present study is feasible, and the new apparatus is effective for use in animal models of cigarette smoke-induced emphysema. This new murine model of cigarette smoke-induced emphysema is a promising and economically viable option for use in studies investigating the pathophysiology of and therapeutic approaches to COPD.

\section{Acknowledgments}

The authors thank José Ricardo Sousa at the Faculdades Integradas Padre Albino (FIPA, Padre Albino Integrated Colleges) for his technical support.

\section{References}

1. World Health Organization. Global Alliance against Chronic Respiratory Diseases (GARD). General Meeting Report; 2008 May 30-31; lstanbul, Turkey. Geneva: WHO; 2008.

2. Global Initiative for Chronic Obstructive Lung Disease [homepage on the Internet. Bethesda: GOLD [cited 2012 Dec 10]. Global Strategy for the Diagnosis, Management and Prevention of COPD---Revised, 2011. Available from: http://www.goldcopd.org/

3. de Faria CA, de las Heras Kozma R, Stessuk T, RibeiroPaes JT. Experimental basis and new insights for cell therapy in Chronic Obstructive Pulmonary Disease. Stem Cell Rev. 2012;8(4):1236-44. http://dx.doi.org/10.1007/ s12015-012-9410-7 PMid:23054962 
4. Ribeiro-Paes JT, Stessuk T, de las Heras Kozma R. Cel Therapy in Chronic Obstructive Pulmonary Disease: State of the Art and Perspectives. In: Ong KC, editor. Chronic Obstructive Pulmonary Disease - Current Concepts and Practice. Rijeka: InTech; 2012. p. 455-74.

5. Churg A, Cosio M, Wright JL. Mechanisms of cigarette smoke-induced COPD: insights from animal models. Am J Physiol Lung Cell Mol Physiol. 2008;294(4): L61231. http://dx.doi.org/10.1152/ajplung.00390.2007 PMid:18223159

6. Wright JL, Cosio M, Churg A. Animal models of chronic obstructive pulmonary disease. Am J Physiol Lung Cell Mol Physiol. 2008;295(1):L1-15. http://dx.doi.org/10.1152/ ajplung.90200.2008 PMid:18456796 PMCid:PMC2494776

7. Fusco L, Pêgo-Fernandes P, Xavier A, Pazetti R, Rivero D, Capelozzi V, Janete F Modelo experimental de enfisema pulmonar em ratos induzido por papaína. J Pneumol. 2002; 28:1-7. http://dx.doi.org/10.1590/ S0102-35862002000100003

8. Antunes MA, Rocco PR. Elastase-induced pulmonary emphysema: insights from experimental models. An Acad Bras Cienc. 2011;83(4):1385-96. http://dx.doi. org/10.1590/S0001-37652011005000039

9. Churg A, Sin DD, Wright JL. Everything prevents emphysema: are animal models of cigarette smokeinduced chronic obstructive pulmonary disease any use? Am J Respir Cell Mol Biol. 2011;45(6):1111-5. http:// dx.doi.org/10.1165/rcmb.2011-0087PS PMid:21685155

10. Cendon SP, Battlehner C, Lorenzi Filho G, Dohlnikoff M, Pereira PM, Conceição GM, et al. Pulmonary emphysema induced by passive smoking: an experimental study in rats. Braz J Med Biol Res. 1997;30(10):1241-7. http://dx.doi. org/10.1590/S0100-879X1997001000017 PMid:9496445

11. Huh JW, Kim SY, Lee JH, Lee JS, Van Ta Q, Kim M, et al. Bone marrow cells repair cigarette smoke-induced emphysema in rats. Am J Physiol Lung Cell Mol Physiol. 2011;301(3):L255-66. http://dx.doi.org/10.1152/ ajplung.00253.2010 PMid:21622846

12. Zheng H, Liu Y, Huang T, Fang Z, Li G, He S. Development and characterization of a rat model of chronic obstructive pulmonary disease (COPD) induced by sidestream cigarette smoke. Toxicology Lett. 2009;189(3):225-34. http:// dx.doi.org/10.1016/j.toxlet.2009.06.850 PMid:19524650

13. Weibel E. Principles and methods for the morphometric study of the lung and other organs. Lab Invest. 1963;12:131-55. PMid:13999512

14. Valença SS, Porto LC. Immunohistochemical study of lung remodeling in mice exposed to cigarette smoke. J Bras Pneumol. 2008;34(10):787-95. http://dx.doi. org/10.1590/S1806-37132008001000006 PMid:19009211

15. Toledo AC, Magalhaes RM, Hizume DC, Vieira RP, Biselli PJ, Moriya HT, et al. Aerobic exercise attenuates pulmonary injury induced by exposure to cigarette smoke. Eur Respir J. 2012;39(2):254-64. http://dx.doi. org/10.1183/09031936.00003411 PMid:21700603

16. D’Agostino B, Sullo N, Siniscalco D, De Angelis A, Rossi F. Mesenchymal stem cell therapy for the treatment of chronic obstructive pulmonary disease. Expert Opin Biol Ther. 2010;10(5):681-7. http://dx.doi. org/10.1517/14712591003610614 PMid:20384521
17. Zhang XY, Zhang C, Sun QY, Li D, Luo RR, Wan ZF, et al. Infliximab protects against pulmonary emphysema in smoking rats. Chin Med J (Engl). 2011;124(16):2502-6.

18. Guerassimov A, Hoshino Y, Takubo Y, Turcotte A, Yamamoto $\mathrm{M}$, Ghezzo H, et al. The development of emphysema in cigarette smoke-exposed mice is strain dependent. Am J Respir Crit Care Med. 2004;170(9):974-80. http://dx.doi. org/10.1164/rccm.200309-12700C PMid:15282203

19. Marumo CK, Otsuki DA, Fantoni DT, Margarido CB, Ambrósio AM, Pelosi P, et al. Hemodynamic effects of PEEP in a porcine model of $\mathrm{HCl}$-induced mild acute lung injury. Acta Anaesthesiol Scand. 2009;53(2):190-202. http://dx.doi.org/10.1111/j.1399-6576.2008.01842.x PMid:19094174

20. Churg A, Wang R, Wang X, Onnervik PO, Thim K, Wright JL. Effect of an MP-9/MMP-12 inhibitor on smoke-induced emphysema and airway remodelling in guinea pigs. Thorax. 2007;62(8):706-13. http://dx.doi.org/10.1136/ thx.2006.068353 PMid:17311841 PMCid:PMC2117295

21. Rinaldi M, Maes K, De Vleeschauwer S, Thomas D, Verbeken EK, Decramer M, et al. Long-term nose-only cigarette smoke exposure induces emphysema and mild skeletal muscle dysfunction in mice. Dis Model Mech. 2012;5(3):333-41. http://dx.doi.org/10.1242/dmm.008508 PMid:22279084 PMCid:PMC3339827

22. Jardim JR, Bizeto L, Fleig Mayer A, Camelier A, Rosa FW, Oliveira D, et al. An inhalation chamber model for controlled studies of tobacco smoke toxicity in rodents [Article in Spanish]. Arch Bronconeumol. 2010;46(9):455-8. http:// dx.doi.org/10.1016/j.arbres.2010.05.012 PMid:20624668

23. Li Y, Li SY, Li JS, Deng L, Tian YG, Jiang SL, et al. A rat model for stable chronic obstructive pulmonary disease induced by cigarette smoke inhalation and repetitive bacterial infection. Biol Pharm Bull. 2012;35(10):1752-60. http://dx.doi.org/10.1248/bpb.b12-00407 PMid:22863994

24. Cataneo AJM, Reibscheid SM. Broncografia e planimetria torácicos -- estudo experimental no rato. J Pneumol. 1988;14(2):66-9.

25. Foronjy RF, Mercer BA, Maxfield MW, Powell CA, D’Armiento J, Okada Y. Structural emphysema does not correlate with lung compliance: lessons from the mouse smoking model. Exp Lung Res. 2005;31(6):547-62. http:// dx.doi.org/10.1080/019021490951522 PMid:16019987

26. Decramer M, De Benedetto F, Del Ponte A, Marinari S. Systemic effects of COPD. Respir Med. 2005;99 Suppl B:S3-10.

27. Gea J, Barreiro E. Update on the mechanisms of muscle dysfunction in COPD [Article in Spanish]. Arch Bronconeumol. 2008;44(6):328-37. http://dx.doi. org/10.1016/S1579-2129(08)60054-3

28. Mineur YS, Abizaid A, Rao Y, Salas R, Dileone RJ, Gündisch $D$, et al. Nicotine decreases food intake through activation of POMC neurons. Science. 2011;332(6035):1330-2. http:// dx.doi.org/10.1126/science.1201889 PMid:21659607 PMCid:PMC3113664

29. Chen BR, Hansen MJ, Jones JE, Vlahos R; Bozinovski S, Anderson GP, et al. Cigarette smoke exposure reprograms the hypothalamic neuropeptide $\mathrm{Y}$ axis to promote weight loss. Am J Respir Crit Care Med. 2006;173(11):124854. http://dx.doi.org/10.1164/rccm.200506-9770C PMid:16531608 


\section{About the authors}

\section{Rodrigo de las Heras Kozma}

Graduate Student. University of São Paulo, São Paulo, Brazil.

\section{Edson Marcelino Alves}

Undergraduate Student. Júlio de Mesquita Filho São Paulo State University at Assis School of Sciences and Languages, Assis, Brazil.

\section{Valter Abraão Barbosa-de-Oliveira}

Graduate Student. University of São Paulo, São Paulo, Brazil.

\section{Fernanda Degobbi Tenorio Quirino dos Santos Lopes}

Researcher. Júlio de Mesquita Filho São Paulo State University, Botucatu, Brazil.

\section{Renan Cenize Guardia}

Undergraduate Student. Faculdades Integradas Padre Albino, Catanduva, Brazil.

\section{Henrique Vivi Buzo}

Undergraduate Student. Faculdades Integradas Padre Albino, Catanduva, Brazil.

Carolina Arruda de Faria

Graduate Student. University of São Paulo, São Paulo, Brazil.

\section{Camila Yamashita}

Undergraduate Student. Júlio de Mesquita Filho São Paulo State University at Assis School of Sciences and Languages, Assis, Brazil.

\section{Manzelio Cavazzana Júnior}

Associate Professor. Faculdades Integradas Padre Albino, Catanduva, Brazil.

\section{Fernando Frei}

Associate Professor. Júlio de Mesquita Filho São Paulo State University at Assis School of Sciences and Languages, Assis, Brazil.

\section{Maria José de Oliveira Ribeiro-Paes}

Associate Professor. Faculdades Integradas Padre Albino, Catanduva, Brazil.

\section{João Tadeu Ribeiro-Paes}

Assistant Professor. Júlio de Mesquita Filho São Paulo State University at Assis School of Sciences and Languages, Assis, Brazil. 